\title{
Numerical Study Characteristics of Heat Transfer on Staggered Cylinder Arrangement
}

\author{
Sulharman $^{1}$ and M.Y. Setiawan ${ }^{2}$
}

\begin{abstract}
This research was conducted to examine the characteristics of heat transfer and heat flux fluctuations of staggered cylinder arrangement. The parameters in this study is Reynolds $8.8 \times 10^{4}$, inlet velocity of $1 \mathrm{~m} / \mathrm{s}$ and inlet temperature of $60^{\circ} \mathrm{C}$. Numerical model used is a 2D model-URANS turbulence model is k-omega SST. The results of this study indicate that increased flow velocity in the narrow area on the second row and third row caused by the staggered arrangement. This led to the distribution of the local Nusselt third highest row two and row after row of the lowest. Highest temperature distribution found in the area and the intensity of the turbulent wake in the third row higher value this is due to the influence of turbulence on the previous line and the arrangement of the cylinders. Effect of heat flux variation of the average Nusselt number appears lower in the heat flux $600 \mathrm{~W} / \mathrm{m}^{2}$ than $200 \mathrm{~W} / \mathrm{m}^{2}$ and $1000 \mathrm{~W} / \mathrm{m}^{2}$, but the third row average Nusselt values coincide with each other. While the average turbulent intensity increases towards the downstream. In the third row with a heat flux of $600 \mathrm{~W} / \mathrm{m}^{2}$ has the highest turbulence intensity, while for the heat flux and heat flux of 200 $\mathrm{W} / \mathrm{m}^{2}$ and $1000 \mathrm{~W} / \mathrm{m}^{2}$ turbulence intensity coincide with each other.
\end{abstract}

Keywords-Staggered cylinder arrangement, heat flux, k-omega SST, turbulent intensity

Abstrak-Penelitian ini dilakukan untuk menguji karakteristik perpindahan panas dan fluktuasi heat flux dari susunan silinder staggered. Parameter-parameter dalam penelitian ini adalah bilangan Reynolds $8,8 x 10^{4}$, kecepatan inlet $1 \mathrm{~m} / \mathrm{s}$ dan temperatur inlet $60^{\circ} \mathrm{C}$. Model numerik yang digunakan adalah model 2D-URANS dengan model turbulensi adalah $k$-omega SST. Hasil penelitian ini menunjukkan bahwa kecepatan aliran meningkat pada daerah yang sempit pada baris ke dua dan baris ke tiga disebabkan oleh susunan staggered. Hal ini menyebabkan distribusi Nusselt lokal baris ke tiga tertinggi kemudian baris dua dan baris satu terendah. Distribusi temperatur tertinggi terdapat pada daerah wake serta intensitas turbulen pada baris ke tiga lebih tinggi nilainya, hal ini disebabkan oleh pengaruh turbulen pada baris sebelumnya dan susunan silinder. Pengaruh variasi heat flux terhadap bilangan Nusselt rerata nampak lebih rendah pada heat flux $600 \mathrm{~W} / \mathrm{m}^{2}$ daripada heat flux $200 \mathrm{~W} / \mathrm{m}^{2}$ dan $1000 \mathrm{~W} / \mathrm{m}^{2}$ namun pada baris ke tiga nilai Nusselt rerata saling berimpit. Sedangkan pada intensitas turbulen rerata semakin meningkat ke arah downstream. Pada baris ke tiga dengan heat flux $600 \mathrm{~W} / \mathrm{m}^{2}$ memiliki intensitas turbulen tertinggi, sedangkan untuk heat flux $200 \mathrm{~W} / \mathrm{m}^{2}$ dan heat flux $1000 \mathrm{~W} / \mathrm{m}^{2}$ intensitas turbulennya saling berimpit.

Kata Kunci-Susunan silinder staggered, heat flux, k-omega SST, intensitas turbulen

\section{INTRODUCTION}

$\mathrm{R}$ esearch on the rate of heat transfer in staggered arrangement of circular cylindrical objects have been carried out experimentally and numerically. The form is usually applied to heat exchangers, cooling rooms, electronic equipment, motor fuel, gas turbine blade trailing edge, compact heat exchanger, with air as the heat transfer media and other engineering applications.

Some experimental studies on the flow in a circular cylindrical objects Zdravkovich [1] shows the results obtained with the greater distance is tehadap body wall then drag the resulting increase in size. It happened on a cylinder with a smaller diameter, while the large diameter drag ratio rises to a certain gap and then back down if the ratio is enlarged.

Scholten, Murray [2], studied heat transfer and velocity fluctuations in unsteady conditions on the cylinder threerow staggered arrangement. Cylinders first line shows that fluctuations in surface heat flux from throughout the region as a result of the vibration velocity vortex shedding. In the next composition variations fluk affected by turbulent eddy heat transport from the flow disturbance vortices shed by the cylinder arrangement.

Sulharman and M.Yasep Setiawan are Master Engineering Student of Mechanical Engineering Department, FTI, Institut Teknologi Sepuluh November, Surabaya, 60111, Indonesia.

Email:sulharman11@mhs.me.its.ac.id
W.A. Khan et.al [3] conducted analytical studies of heat transfer in the flow tube banks staggered perpendicular and parallel to the isothermal boundary condition. That the average heat transfer coefficient for tube banks that passed perpendicular to the flow depends on the longitudinal and transversepitches, Reynolds and Prandtl numbers.

Ertan Buyruk [4] conducted experiments on the effects of blockage ratio on the local Nusselt number and pressure coefficient on the cylinder staggered arrangement. Distribution of Nusselt number and pressure coefficient is very different to the blockage ratio in $0668-0843$.

This study aimed to investigate the characteristics of heat transfer in numerical simulations on staggered arrayed on a circular cylinder Reynolds number (ReD) 8.8 with various models of heat flux.Turbulen URANS $\mathrm{k}-\omega \mathrm{SST}$. Analysis of the numerical study conducted in 2dimensional (2D). By knowing the characteristics of the heat transfer can help an engineer for planning heat exchanger, cooling room, electronic equipment, motor fuel, gas turbine using staggered cylinder arrangement.

\section{METHOD}

1. Using The Reynolds Averaged Navier Stokes Equations Mass and Momentum: $\frac{\partial u_{i}}{\partial x_{i}}$ 
$\frac{\partial u_{i}}{\partial t}+u_{j} \frac{\partial u_{i}}{\partial u_{j}}=-\frac{1}{\rho}\left(\frac{\partial P}{\partial x_{i}}\right)+v\left(\frac{\partial^{2} u_{i}}{\partial x_{j}^{2}}\right)-\frac{\overline{\partial u_{i}^{\prime} u_{j}^{\prime}}}{\partial x_{j}}$

where $\mathrm{i}, \mathrm{j}=1,2$. Here $\mathrm{x}_{1}$ and $\mathrm{x}_{2}$ indicate horizontal and vertical directions, respectively; $\mathrm{u}_{1}$ and $\mathrm{u}_{2}$ is the average velocity component; $\overline{u_{1}^{s} u_{j}^{s}}$ Reynolds stress components which $u_{i}^{s}$ are fluctuating velocity, $\mathrm{P}$ is pressure, and $\rho$ is the density of the fluid.

Reynolds stress component, $\overline{u_{0}^{s} u_{j}^{s}}$, is expressed in the turbulent viscosity and the average gradient flow using Boussinesq approach,

$\overline{u_{i}^{\prime} u_{j}^{\prime}}=-v_{T}\left(\frac{\partial u_{i}}{\partial x_{j}}+\frac{\partial u_{j}}{\partial x_{i}}\right)-\frac{2}{3} k \delta_{i j}$

Where $\mathrm{k}$ is the turbulent kinetic energy and is the Kronecker function. Now the researchers are using the standard high Reynolds number k- $\varepsilon$ turbulence modeling. This model has been applied for the vortex shedding flow. $\mathrm{K}$ and $\varepsilon$ equations shown:

$$
\begin{aligned}
& \frac{\partial k}{\partial t}+u_{j} \frac{\partial k}{\partial x_{j}}=\frac{\partial}{\partial x_{j}}\left(\frac{v T}{\sigma_{k}} \frac{\partial k}{\partial x_{j}}\right)+V_{T}\left(\frac{\partial u_{i}}{\partial x_{j}}+\frac{\partial u_{j}}{\partial x_{i}}\right) \frac{\partial u_{i}}{\partial x_{j}}-\varepsilon \\
& \frac{\partial \varepsilon}{\partial t}+u_{j} \frac{\partial \varepsilon}{\partial x_{j}}=\frac{\partial}{\partial x_{j}}\left(\frac{v_{T}}{\sigma_{\varepsilon}} \frac{\partial \varepsilon}{\partial x_{j}}\right)+C_{1} \frac{\varepsilon}{k} v_{T}\left(\frac{\partial u_{i}}{\partial x_{j}}+\frac{\partial u_{j}}{\partial x_{i}}\right) \frac{\partial u_{i}}{\partial x_{j}} \\
& -C_{2} \frac{\varepsilon^{2}}{k}
\end{aligned}
$$

Where $v_{T}=C \mu\left(k^{2} / \varepsilon\right)$ for standardized coefficients taken from $\left(\mathrm{C}_{1}=1,44 ; \mathrm{C}_{2}=1,92 ; \mathrm{C} \mu=0,09 ; \sigma_{\mathrm{k}}=1,00 ; \sigma_{\varepsilon}=\right.$ $1,3)$.

\section{Model turbulent Shear-Stress-Transport (SST) k- $\omega$}

K-omega turbulence model SST is a combined model of accurate turbulent flow near the wall and away from the wall also includes adverse pressure gradient [5].

\section{Distribution Nusselt Number}

Distribution $\mathrm{Nu}_{\Phi}$ dimensionless numbers formed from the following equation :

$N u_{\Phi}=\frac{h \cdot L_{c}}{k_{f}}=\frac{\frac{q}{T_{w}-T_{i n}} L_{c}}{k_{f}}$

where: $\mathrm{q} "=$ local heat flux $\left(\mathrm{W} / \mathrm{m}^{2}\right), \mathrm{Tw}=$ temperature of the surface of the tube wall $(\mathrm{K})$; Tin = inlet air temperature $(\mathrm{K})$; Lc $=$ characteristic length $(\mathrm{m})$. While the average Nusselt number is calculated from the following equation:

$\overline{N u}=\frac{\int N u_{\Phi} d A_{s}}{\int d A_{s}}$

where; As = area of blanket cylinder $\left(\mathrm{m}^{2}\right)$

\section{Numerical Model}

In the numerical model, the researcher must be careful attention to data accuracy meshing. Giving meshing are concerned especially important in areas where the terrain is the boundary layer on the diamana close the grid of meshing in to get valid. The dimensions used are $24 \mathrm{D} \mathrm{x}$ 6.5D, $0.25 \mathrm{D}$ of $\mathrm{G}$ wall diameter of $1 \mathrm{~m}, \mathrm{~S} 1: 25 \mathrm{D}, \mathrm{T} 2.5 \mathrm{D}$ The flow rate used was $1 \mathrm{~m} / \mathrm{s}$ (See Figure 1). In this study researchers using 4 pieces of the mesh A, B, C and $\mathrm{D}$ respectively mesh can be seen in Table 1 . At one table we can see that the meshing of $\mathrm{C}$ has value to the experimental error is smaller than other mesh, mesh $\mathrm{C}$ so it can be concluded that the best use.

\section{RESULT AND DISCUSSION}

\section{A. Flow Pattern}

The contour of velocity of fluid flow across the sevencylinder arrangement with staggered three-line flux variations with a speed of $1 \mathrm{~m} / \mathrm{s}$ is shown in Figure 4.

From the three images above it can be seen that the overall flow direction $x$ each entered the gap between the cylinder and also an increase in acceleration between the cylinder wall above and below. This occurs due to narrowing of the flow area by staggered arrangement when crossing the area between the cylinders. At the cylinders 1, 2, and 4 appear wake than the other cylinders. Differences were also seen on the side of the inlet and outlet due to the greater heat flux.

Temperature distribution in the air at the time of passing the seven-cylinder shown in the Figure 5. Temperatur highest air contained in the wake of each cylinder. Intensity contours of turbulent fluid flow across seven staggered cylinder arrangement with flux variations at a speed of $1 \mathrm{~m} / \mathrm{s}$ is shown in Figure 6 .

From Figure 6 on top of the cylinder 6 and 7 have a higher intensity in the turbulent than the other cylinders. This is due to high turbulent consequences caused by the two previous lines.

Average turbulent intensity (IT) for each cylinder is described in Figure 7. At positions 1 to 4 looks turbulent intensity increased. In the third row with a heat flux 600 $\mathrm{W} / \mathrm{m} 2$ has the highest turbulence intensity, while for heat flux $200 \mathrm{~W} / \mathrm{m}^{2}$ and $1000 \mathrm{~W} / \mathrm{m}^{2}$ heat flux turbulent intensity coincide with each other.

\section{B. Heat Transfer Characteristic}

Distribution of the local Nusselt number $\left(\mathrm{Nu}_{\Phi}\right)$ on each cylinder (tube) with a variation of heat flux is shown in Figure 8.

From Figure 8 below the front cylinder of the stagnation point $(\Phi=00)$ to the point of separation $(\Phi=$ 1200) seen a big difference between each cylinder at each heat flux. Third row (cylinder 6 and 7) have a distribution of local Nusselt number is higher than the rows and rows of two to one this is due to high turbulent consequences caused by the two previous lines. The maximum local Nusselt number seen in 730, 770, 800 and minimum Nusselt numbers look the same on each heat flux 1270. In the wake area for heat flux $200 \mathrm{~W} / \mathrm{m}^{2}$ local Nusselt value is higher than the 600 and 1000 $\mathrm{W} / \mathrm{m}^{2}$

Average Nusselt number $(\mathrm{Nu})$ is shown in Figure 9. For the lowest $\mathrm{Nu}$ heat flux occurs at $600 \mathrm{~W} / \mathrm{m}^{2}$ for the first line and second line to the third, while the increase due to the influence of heat distribution on the previous line. For a heat flux of 200 and $1000 \mathrm{~W} / \mathrm{m}^{2}$ coincide well with each other from the first row to the third row.

\section{CONCLUSION}

Two-dimensional numerical simulations have been conducted to determine the effect of heat flux (200 $\mathrm{W} / \mathrm{m}^{2}, 600 \mathrm{~W} / \mathrm{m}^{2}$, and $1000 \mathrm{~W} / \mathrm{m}^{2}$ ) on the characteristics 
of flow and heat transfer on circular cylinder with a staggered arrangement.

From the numerical simulations is obtained that the flow velocity increases in a narrow area on the second row and third row caused by the staggered arrangement. This led to the distribution of the local Nusselt value in the third row then the second row and the highest of the lowest row. Highest temperature distribution is in the region as well as the intensity of the turbulent wake in the $3^{\text {rd }}$ row is higher the value, this is due to the influence of turbulence on the previous line and cylinder arrangement.

Effect of heat flux variation of the average Nusselt number appears lower in the heat flux $600 \mathrm{~W} / \mathrm{m}^{2}$ for the first line and second line to the third, while the increase due to the influence of heat distribution on the previous line. While the average turbulent intensity increases towards the downstream. In the third row with a heat flux of $600 \mathrm{~W} / \mathrm{m}^{2}$ has the highest turbulence intensity, while for the heat flux and heat flux of $200 \mathrm{~W} / \mathrm{m}^{2} 1000$ $\mathrm{W} / \mathrm{m}^{2}$ turbulent intensity coincide with each other.

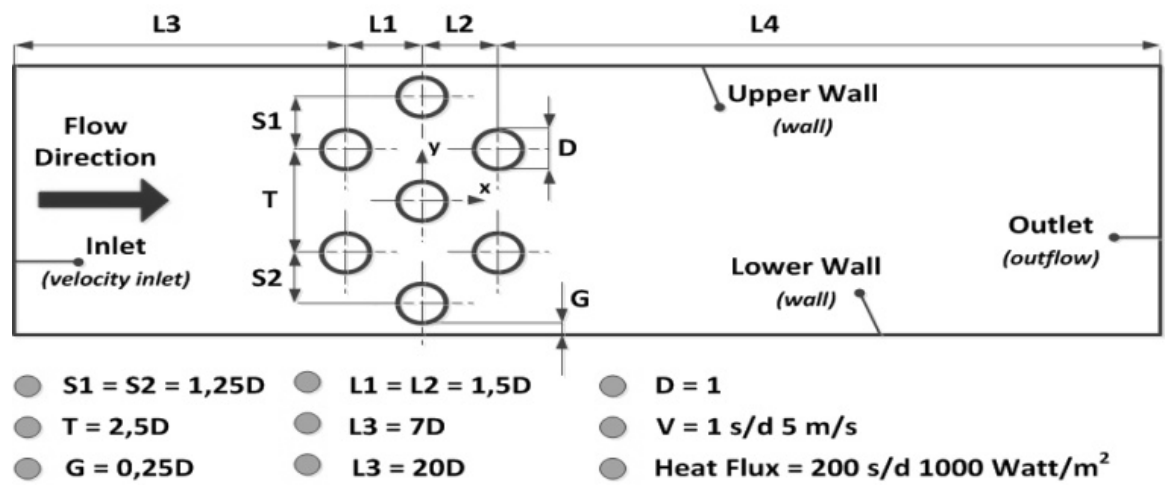

Figure 1. Geometry model

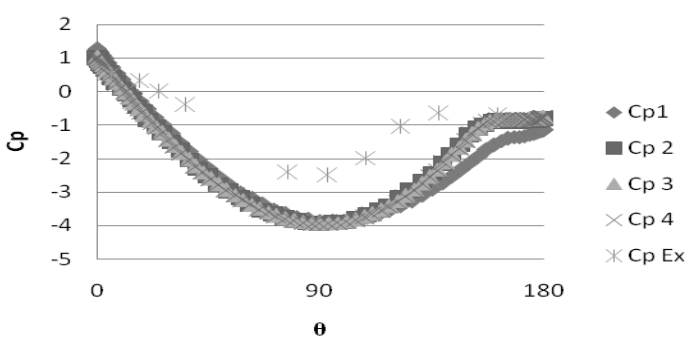

Figure 2. Graph of mean pressure distribution on the cylinder

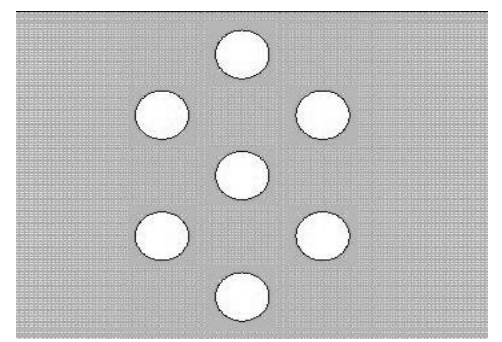

Figure 3. Total mesh shape

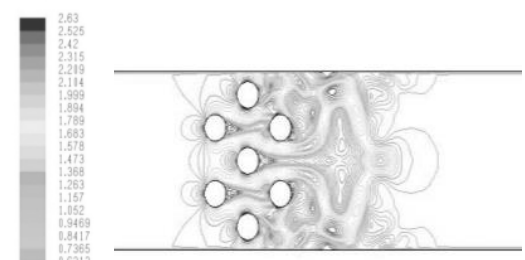

(a)
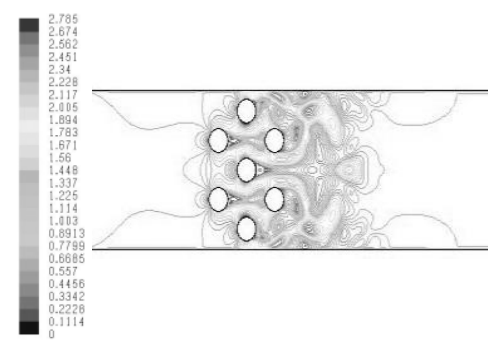

(b)
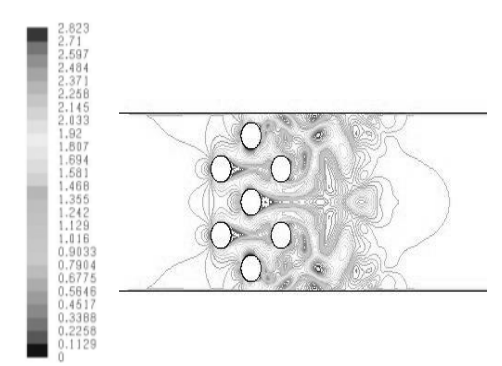

(c)

Figure 4. Contour speed with the variation of heat flux of (a) $200 \mathrm{~W} / \mathrm{m}^{2}$, (b) $600 \mathrm{~W} / \mathrm{m}^{2}$, and (c) $1000 \mathrm{~W} / \mathrm{m}^{2}$

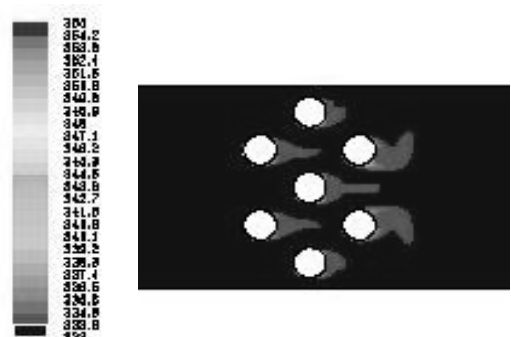

(a)
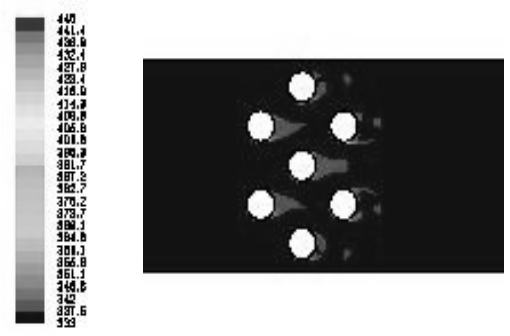

(b)
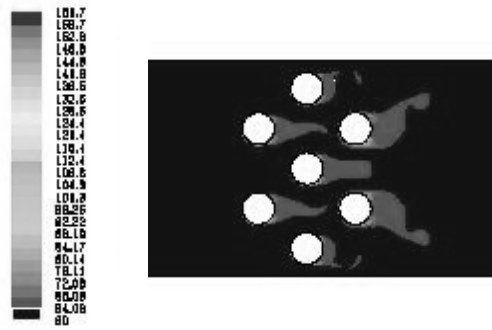

(c)

Figure 5. Total temperature contours with heat flux variations of (a) $200 \mathrm{~W} / \mathrm{m}^{2}$, (b) $600 \mathrm{~W} / \mathrm{m}^{2}$, and (c) $1000 \mathrm{~W} / \mathrm{m}^{2}$ 


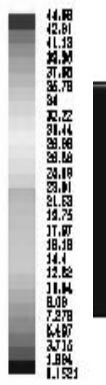

(a)

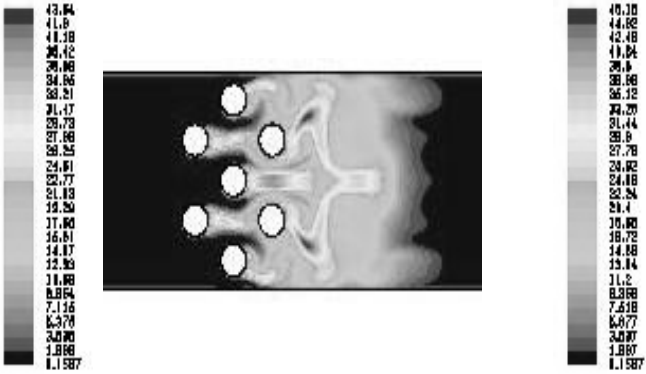

(b)

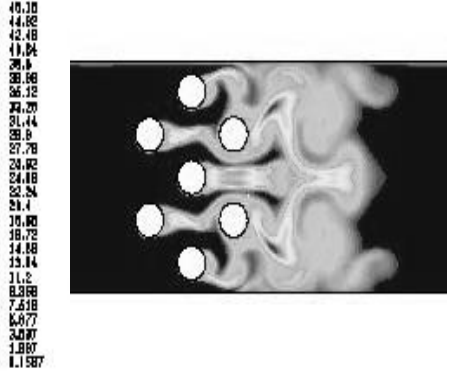

(c)

Figure 6. Contours of turbulence intensity with heat flux variations of (a) $200 \mathrm{~W} / \mathrm{m}^{2}$, (b) $600 \mathrm{~W} / \mathrm{m}^{2}$, and (c) $1000 \mathrm{~W} / \mathrm{m}^{2}$

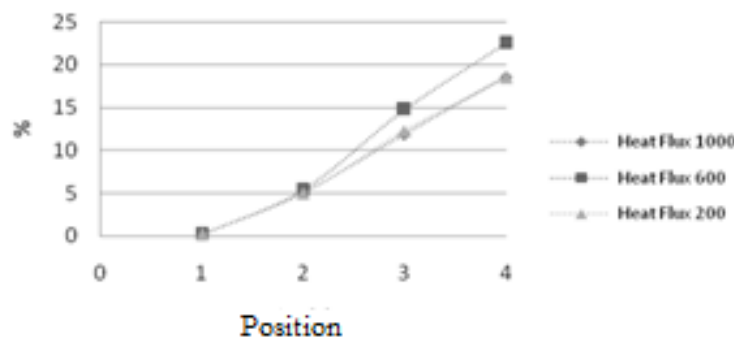

Figure 7. Intensity of the turbulent heat flux variation $\left(\mathrm{W} / \mathrm{m}^{2}\right)$

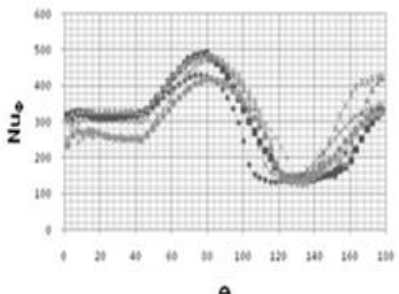

(a)

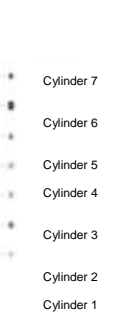

chloris

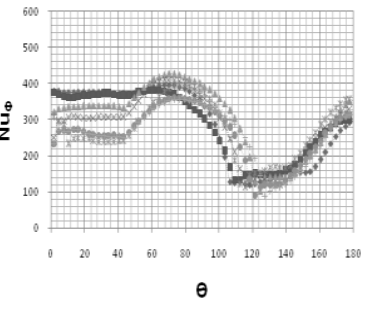

(b)

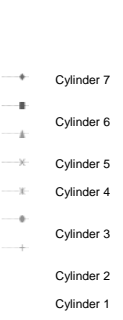

cyinder 1

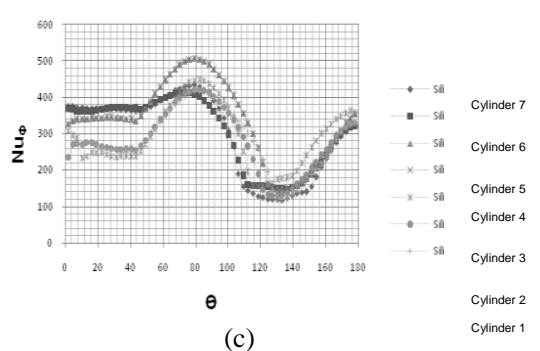

(c)

Figure 8. Distribution of Local Nusselt number with heat flux variations of (a) $200 \mathrm{~W} / \mathrm{m}^{2}$, (b) $600 \mathrm{~W} / \mathrm{m}^{2}$, and (c) $1000 \mathrm{~W} / \mathrm{m}^{2}$

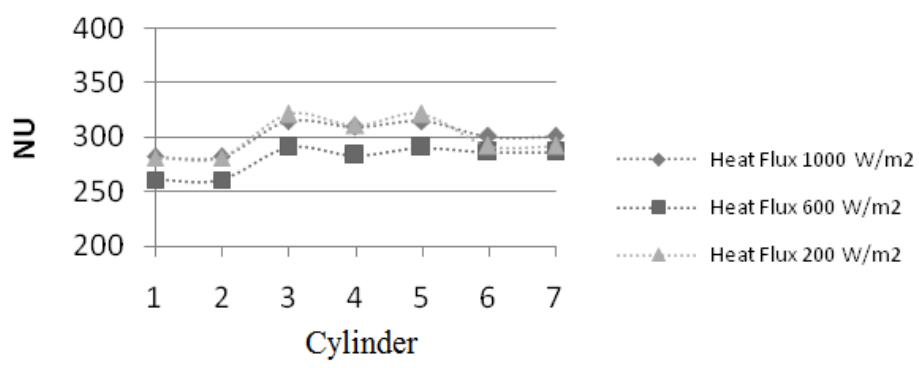

Figure 9. Distribution of mean Nusselt number with the variation of heat flux $\left(\mathrm{W} / \mathrm{m}^{2}\right)$

\section{REFERENCES}

[1] M.M. Zdravkovich, "Forces on a Circular Cylinder Near a Plane Wall", Applied Ocean Research, vol 7, o.4, University of Salford, Salford-UK,

[2] J.W. Scholten and DB Murray, "Heat transfer and velocity Fluctuations in a staggered Tubearray". International Journal of Heat and Fluid Flow 19, pp. 233- 244, 1998.

[3] W.A. Khan, J.R. Culham, and M.M. Yovano. "Convection heat transfer from tube banksin crossflow: Analytical Approach". International Journal of Heat and Mass Transfer 49, pp.48314838, 2006.
[4] B. Ertan, "Heat Transfer and Flow Structures Around Circular Cylinders in Cross-Flow".Tr. J. of Engineering and Environmental Science 23, pp. 299-315, 1999.

[5] J. Nicholas, Mulvany, L. Chen, Y.J. Tu, and B.Anderson, 'Steady-State Evaluation of 'Two-Equation' rans (Reynoldsaveraged Navier-Stokes) Turbulence Models for High-Reynolds Number Flow Hydrodynamic simulations", Defence Science and Technology Organisation, 2004. 